\title{
CARBONATE ROCKS OF THE ADAVERE STAGE AND POSSIBILITIES OF THEIR UTILIZATION (SILURIAN, ESTONIA)
}

\begin{abstract}
Aada TEEDUMÃE
Geoloogia Instituut (Institute of Geology), Estonia pst. 7, EE-0001 Tallinn, Eesti (Estonia)

Presented by V. Puura

Received 7 June 1995, accepted 10 October 1995

Abstract. In the belt of outcrops of the Adavere Stage there have been distinguished four areas differing in the lithological composition of the sections, corresponding properties and possible fields of use of rocks, and prospects for revealing workable deposits. The reasons of lithological variability are discussed, the assessment of the geological preconditions for the existence of potential commercial resources of carbonate rocks is presented.
\end{abstract}

Key words: lithology, carbonate rocks, mineral resources, Silurian, Estonia.

\section{INTRODUCTION}

The Adavere Stage corresponds to the traditional upper Llandovery. It is divided (Решения ..., 1987) into two parts: the lower Rumba Formation and the upper Velise Formation. The boundary between these formations has been considered as a chronostratigraphical boundary (Эйнасто et al., 1972). In the eastern part of the outcrop of the stage there has been distinguished the Mõhküla Member (Юргенсон, 1966; Кальо, 1970), which later was raised to the rank of the formation (Kaljo, 1990 ) as laterally replacing the Rumba Formation.

In the present study the unified regional stratigraphical chart (Peweния..., 1987) is used treating the Mõhküla Formation as an independent lithostratigraphical unit of the Adavere Stage. The chronostratigraphical position of the formation is disputable and at present it is supposed to belong to the Raikküla Stage (Perens, 1992).

In the following the distribution patterns of lithologically different rock types and their characteristics will be discussed and the respective zonation of the belt of outcrops will be presented, based on the initial data of geological explorations of deposits and mapping (reports and manuscripts of the Geological Survey of Estonia), as well as the author's studies of Rõstla quarry.

\section{DISTRIBUTION AND CHARACTERISTICS OF ROCK TYPES}

The outcrops of the Adavere Stage extend as an almost west-east trending belt from Hiiumaa Island through Central Estonia up to the outcrop of Devonian sediments (Fig. 1). The western part of the belt is quite narrow; it widens abruptly east of the Paide-Pärnu tectonical 
disturbance zone (Vaher, 1991). The lithology of the Adavere Stage is variable (Fig. 2). Depending on the depositional environment, there are noted great changes in the sequence as to the east the shelf sediments replace those of the deeper basin. Based on the lithological variability, several subdivisions of different rank, volume, and stratigraphical position have been distinguished (Юргенсон, 1966; Кальо, 1970; Эйнасто et al., 1972; Kaljo, 1990; Perens, 1992).

As far as the properties of rocks first of all depend on the lithological composition, the following mineral-related characterization of the Adavere Stage is based on lithostratigraphical units, formations. The possible variation of their stratigraphical position does not affect the description presented below.

The Mõhküla Formation represents the lowermost part of the stage on the territory between Eidapere and the Paide-Pärnu tectonical disturbance zone, but in eastern sections it forms the entire thickness of the stage (Fig. 2). Lithologically it consists predominately of finely crystalline secondary dolomite with the intercalations of highly argillaceous dolomite and domerite. On some levels there occurs medium- to coarsecrystalline dolomite. Caverns, chalcedony nodules, relicts (in places silicified) of skeletal debris of fossils, and accumulations of finely crystalline pyrite are quite characteristic of the whole section. In the well-known area of sulphide $\mathrm{Pb}-\mathrm{Zn}$ mineralization around Vōhma-Vaki (Пальмре, 1960 ), the crystals of galenite and sphalerite as well as the breccia dolomite are quite common in the topmost part of the section (Fig. 2).

Among fossils best identifiable are brachiopods, corals, stromatoporoids, and trace fossils. The assemblage of fossils and the generally low rhythmically changing content of terrigenous material permit us to treat the Mõhküla Formation as a typical unit of the shallow-water facies (Nestor, 1990). However, neither the position of the formation in the lateral geological succession (Fig. 2) nor the location of its outcrop (Fig. 1) quite associates with the normal distribution of facies belts in the palaeobasin. This anomaly might be explained by mutual impact of the Paide-Pärnu tectonical disturbance, the eastern wing of which is lifted by about $10 \mathrm{~m}$, and of a probable stratigraphical hiatus west or southwest of the distribution of the formation. This allows us to interpret the Mõhküla Formation not as laterally substituting the contemporaneous Rumba Formation (Kaljo, 1990), but as a lithostratigraphical unit of earlier age.

The exact stratigraphical position of the Mõhküla Formation forming the uppermost part of the Raikküla Stage or the lowermost part of the Adavere Stage can be fixed after the correlation, based on microfossils resistant to dolomitization. The material presently available for this correlation is insufficient. Identification of macrofossils is quite complicated due to secondary dolomitization which makes them unsuitable for chronostratigraphical purposes.

The chemical composition of dolomites is variable (Кийпли, 1984) depending on the content of terrigenous material. The purest dolomite contains $\mathrm{CaO} 28-29 \%, \mathrm{MgO} 20-21 \%$, insoluble components $4-6 \%$ (Table). The composition of argillaceous dolomite is more variable: $\mathrm{CaO}$ $25-29 \%, \mathrm{MgO} 16-19 \%$, insoluble components $10-16 \%$.

The geological preconditions for discovering commercially significant deposits of chemically pure dolomite suitable for the production of colourless glass, for the use in metallurgical and chemical industry, are minimal. The content of impurities $\left(\mathrm{Fe}_{2} \mathrm{O}_{3}, \mathrm{SiO}_{2}\right)$ is higher than permitted, except some restricted parts of the section or single layers. In general, dolomites contain rarely $\mathrm{Fe}_{2} \mathrm{O}_{3}$ less than $0.2 \%$. The purest dolomite, with the insoluble part below $5 \%$, may be used in glass industry for the manufacture of glassware without limitations on colour. 


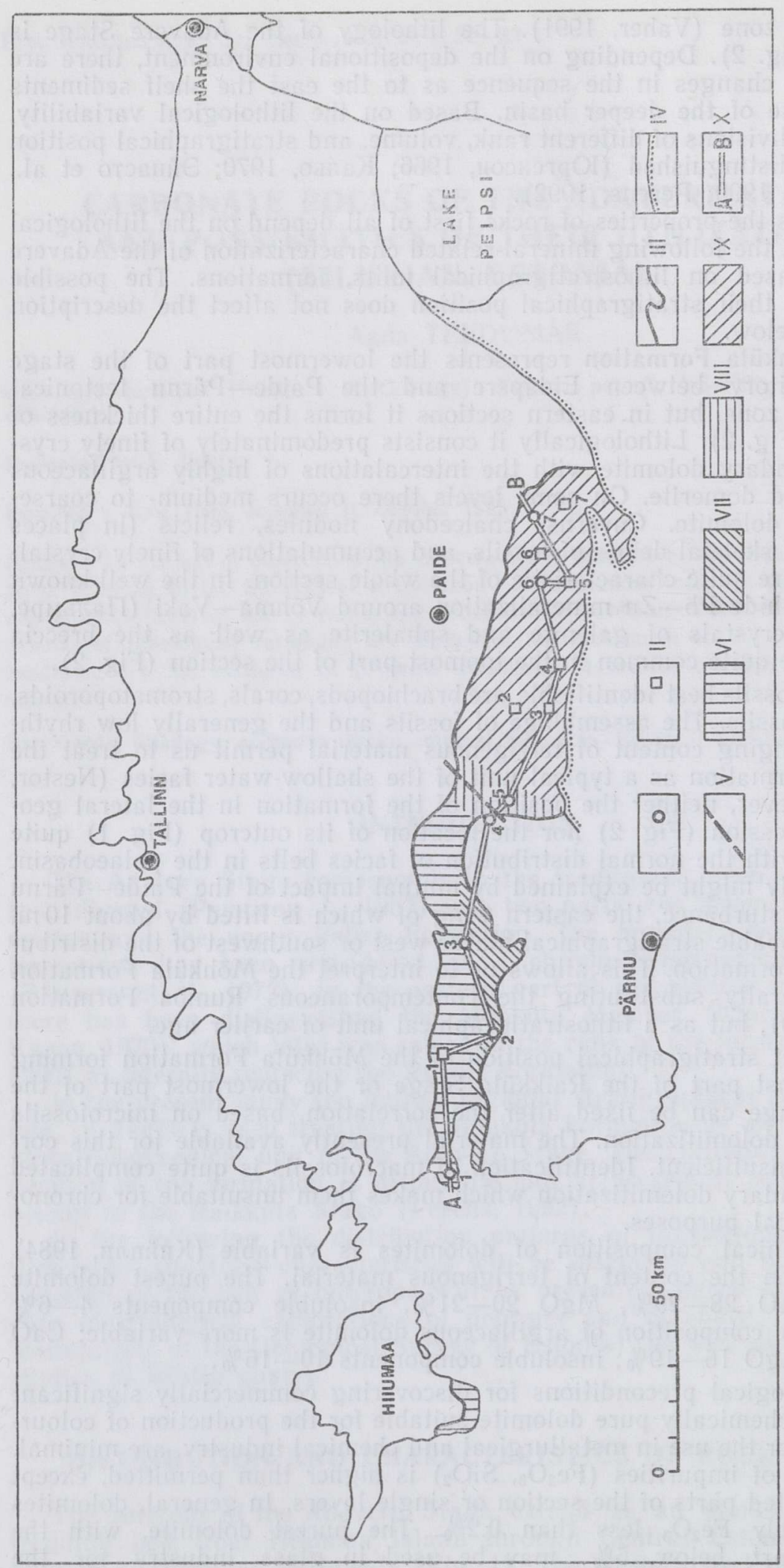

“

인 $\underline{3} \geqslant * i$

- in

$\cong 50$

แ⿻

० की का

ड़워

잉 0

$>$ 趂深

‥ 잉

क $3 \ldots$

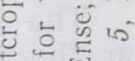

की

फ

एक

- 0 के

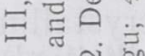

i $=0$

능

告员的

$\neq$ ह

등 छ

$=b_{0}^{\circ}$

용

인

E空 践

证恶

है

七 $0 \frac{0}{0}$

$\div$ ⿻

돈도

๑ $\stackrel{0}{\circ}$

응 을

응전

- 튼

कิ $\frac{1}{0} \frac{0}{0}$

는 표

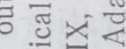

응 $\div 6$

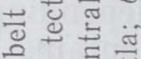

윽 $>0$

品宾引。

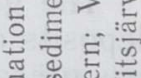

क क

․ 픔

के 


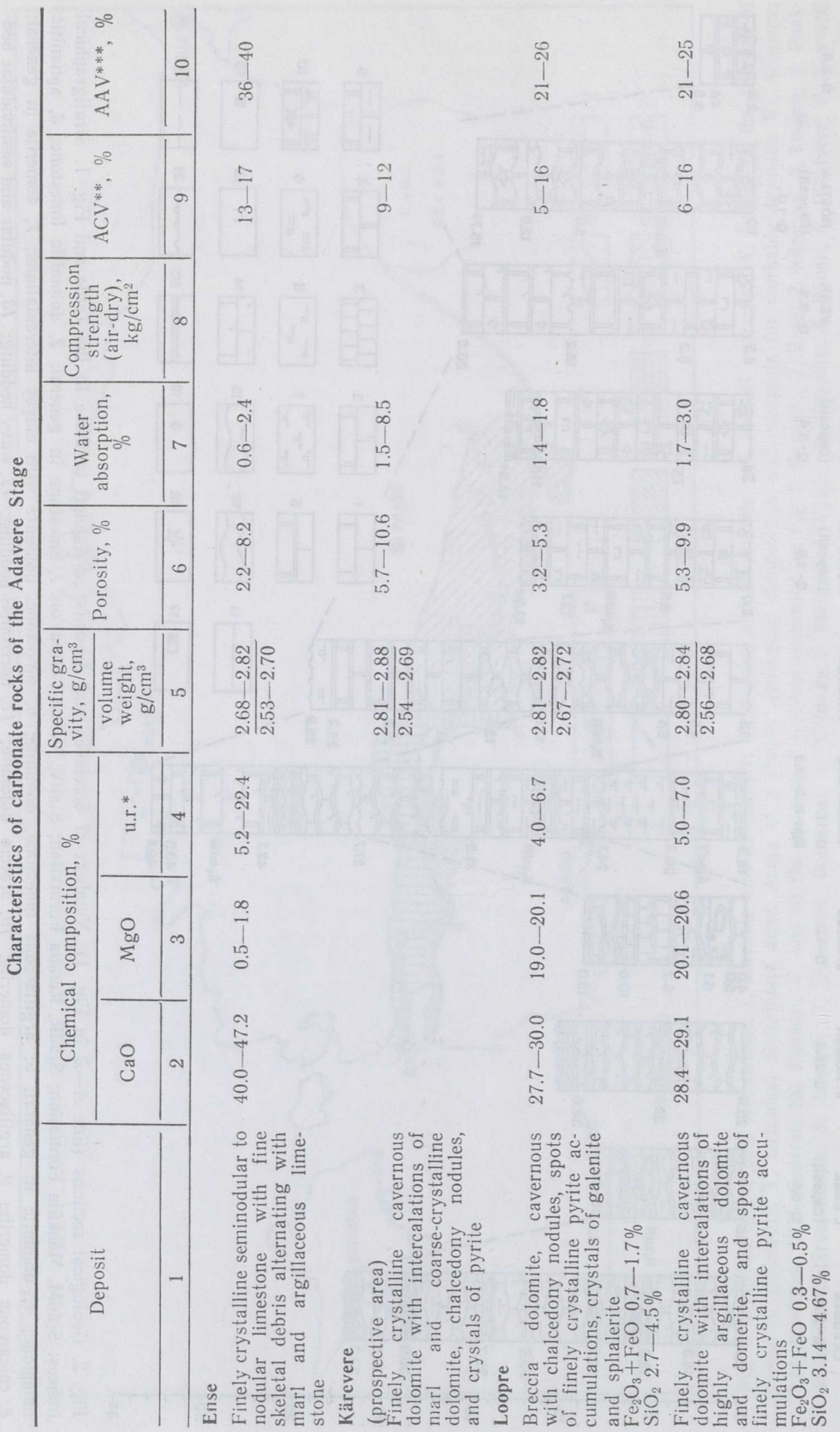




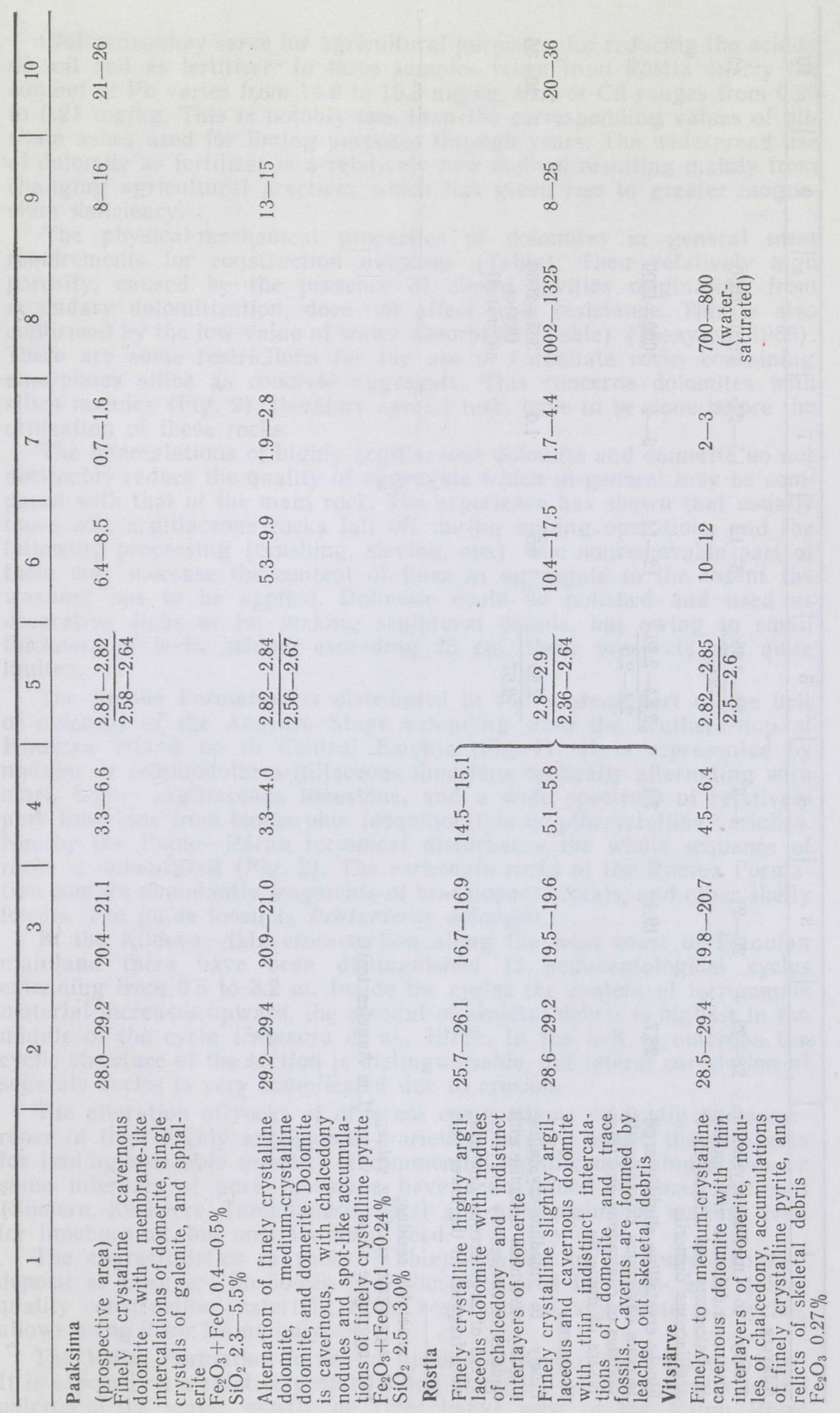




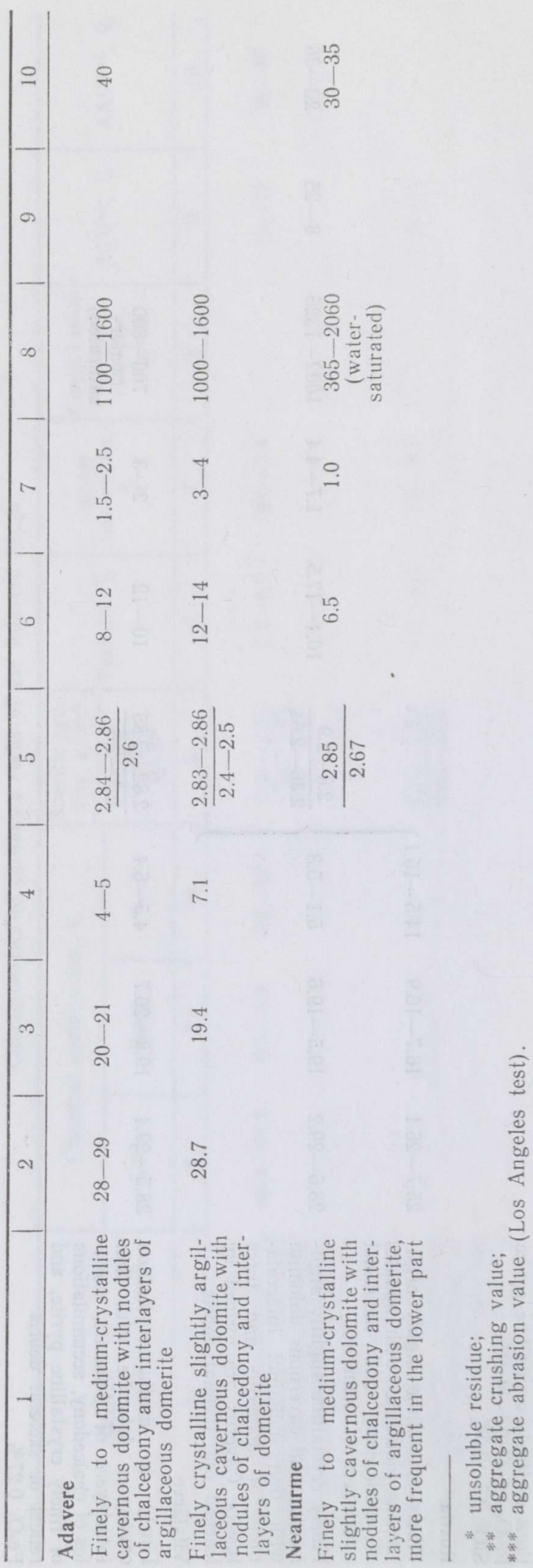


Dolomites may serve for agricultural purposes: for reducing the acidity of soil and as fertilizer. In three samples taken from Rõstla quarry the content of $\mathrm{Pb}$ varies from 14.0 to $15.3 \mathrm{mg} / \mathrm{kg}$, that of $\mathrm{Cd}$ ranges from 0.20 to $0.21 \mathrm{mg} / \mathrm{kg}$. This is notably less than the corresponding values of oilshale ashes used for liming purposes through years. The widespread use of dolomite as fertilizer is a relatively new method resulting mainly from changing agricultural practices which has given rise to greater magnesium deficiency.

The physical-mechanical properties of dolomites in general meet requirements for construction purposes (Table). Their relatively high porosity, caused by the presence of closed cavities originating from secondary dolomitization, does not affect frost resistance. This is also confirmed by the low value of water absorption (Table) (Тээдумяэ, 1986). There are some restrictions for the use of carbonate rocks containing amorphous silica as concrete aggregate. This concerns dolomites with silica nodules (Fig. 2), therefore special tests have to be done before the utilization of these rocks.

The intercalations of highly argillaceous dolomite and domerite do not noticeably reduce the quality of aggregate which in general may be compared with that of the main rock. The experience has shown that usually those soft argillaceous rocks fall off during mining operations and the following processing (crushing, sieving, etc.). The nonremovable part of them may increase the content of fines in aggregate to the extent the washing has to be applied. Dolomite could be polished and used as decorative slabs or for making sculptural details, but owing to small thickness of beds, seldom exceeding $25 \mathrm{~cm}$, these prospects are quite limited.

The Rumba Formation is distributed in the western part of the belt of outcrops of the Adavere Stage extending from the southern top of Hiiumaa Island up to Central Estonia (Fig. 1). It is represented by nodular or seminodular argillaceous limestone cyclically alternating with marl, highly argillaceous limestone, and a wide spectrum of relatively pure limestone from biomorphic (coquinoid) to cryptocrystalline varieties. Nearby the Paide-Pärnu tectonical disturbance the whole sequence of rocks is dolomitized (Fig. 2). The carbonate rocks of the Rumba Formation contain abundantly fragments of brachiopods, corals, and other shelly fossils. The guide fossil is Pentamerus oblongus.

In the Kiideva-Ikla cross-section along the west coast of Estonian mainland there have been distinguished 12 sedimentological cycles extending from 0.5 to $3.2 \mathrm{~m}$. Inside the cycles the content of terrigenous material increases upward, the amount of skeletal debris is highest in the middle of the cycle (Эйнасто et al., 1972). In the belt of outcrops the cyclic structure of the section is distinguishable, but lateral correlation of separate cycles is very complicated due to erosion.

The alteration of rocks of different composition, especially the occurrence of their highly argillaceous varieties, largely reduce the prospects for finding workable deposits of commercial significance. Single beds or some intervals of pure limestone have been mined in small quarries (Sõmeru, Keskvere, Tammikääre, Päri) and used mainly in walling even for limeburning, but only for local need.

The characteristics of rocks (Table), studied in the only explored deposit at Ense are far lower than those required for high- and stablequality construction materials. Frost resistance of aggregate, 15 cycles, allows using it for filling only.

The Velise Formation forms the uppermost part of the Adavere Stage. It is exposed on a relatively narrow belt along the southern border of the outcrop of the stage, mostly on river banks west of the Valgu River 
(Klaamann, 1984) up to the Saastna Cape on the south coast of Matsalu Bay (Fig. 1).

The formation is represented by alternating calcitic, dolomitic, and argillaceous marls, domerite, and thin layers of fine-nodular argillaceous limestone. This shows an abrupt change in the lithological composition of the section, as the strata of the shallow-water Rumba Formation replace the deep-water Velise Formation. Concurrent changes in the association of fossils (Kaljo, 1990) indicate the developing transgression during Velise age. Characteristic of the whole section are metabentonite layers (Юргенсон, 1964) occurring more frequently south of the belt of outcrops. Because of the developing transgression mentioned, the distribution area of the corresponding sediments ought to have originally been more extensive than that of the Rumba Formation. Owing to extremely low erosion resistance of highly argillaceous rocks and the uplift of the eastern wing of the Paide-Pärnu tectonical disturbance, the present area of distribution does not extend far to the east from Valgu and to the north from the southern border of the outcrop of the stage.

The variable, but in general high content of terrigenous material does not allow us to use the rocks of the Velise Formation for any traditional or new purposes.

\section{ZONATION OF THE BELT OF OUTCROPS}

According to differences in the lithology of the sequence and relevant mineral composition and properties of rocks, there can be distinguished four areas (Fig. 1) differing in the possibilities of exploitation as well as prospects for the discovery of workable deposits.

1. The Western area embraces the territory from Hiiumaa Island up to the Sauga River north of the south coast of Matsalu Bay. In this region there occurs the up to $20 \mathrm{~m}$ thick complex of alternating marls, argillaceous limestone, various bioclastic limestone, and cryptocrystalline limestone of the Rumba Formation. The commercial significance of this region is limited to local needs only. The layers of comparatively pure limestone are far from sufficient to form a workable deposit. Nevertheless, selective quarrying would allow extraction of some amount of limestone suitable for construction purposes. The only deposit explored for getting filling material for the reconstruction of roads is Ense but it has not been taken into use up to now.

2. The Southern area forms a narrow belt along the southern border of the Western area. On this territory the rocks of the Rumba Formation are overlain by the highly argillaceous complex of marls, domerite, and limestone of the Velise Formation. This area has no prospects for revealing resources suitable for use.

3. The Central area lies between the Sauga and Pärnu rivers. In this area the whole sequence of rocks is dolomitized. The upper part of the section is represented by the argillaceous dolomite of the Rumba Formation. Its thickness west of the Paide-Pärnu tectonical disturbance is about $20 \mathrm{~m}$, directly to the east about $10 \mathrm{~m}$, farther diminishing rapidly (Fig. 2). The Rumba Formation is underlain by up to $13 \mathrm{~m}$ thick dolomites of the Mõhküla Formation. This region possesses resources of dolomite which may satisfy only local needs for construction purposes, mainly as building stone.

4. The Eastern area embraces the outcrop of the Mõhküla Formation. On this wide territory, bounded from the south and east by the outcrop of Devonian sediments, the thickness of dolomites is up to $15 \mathrm{~m}$. These dolomites, characterized by a variable but in general low content of 


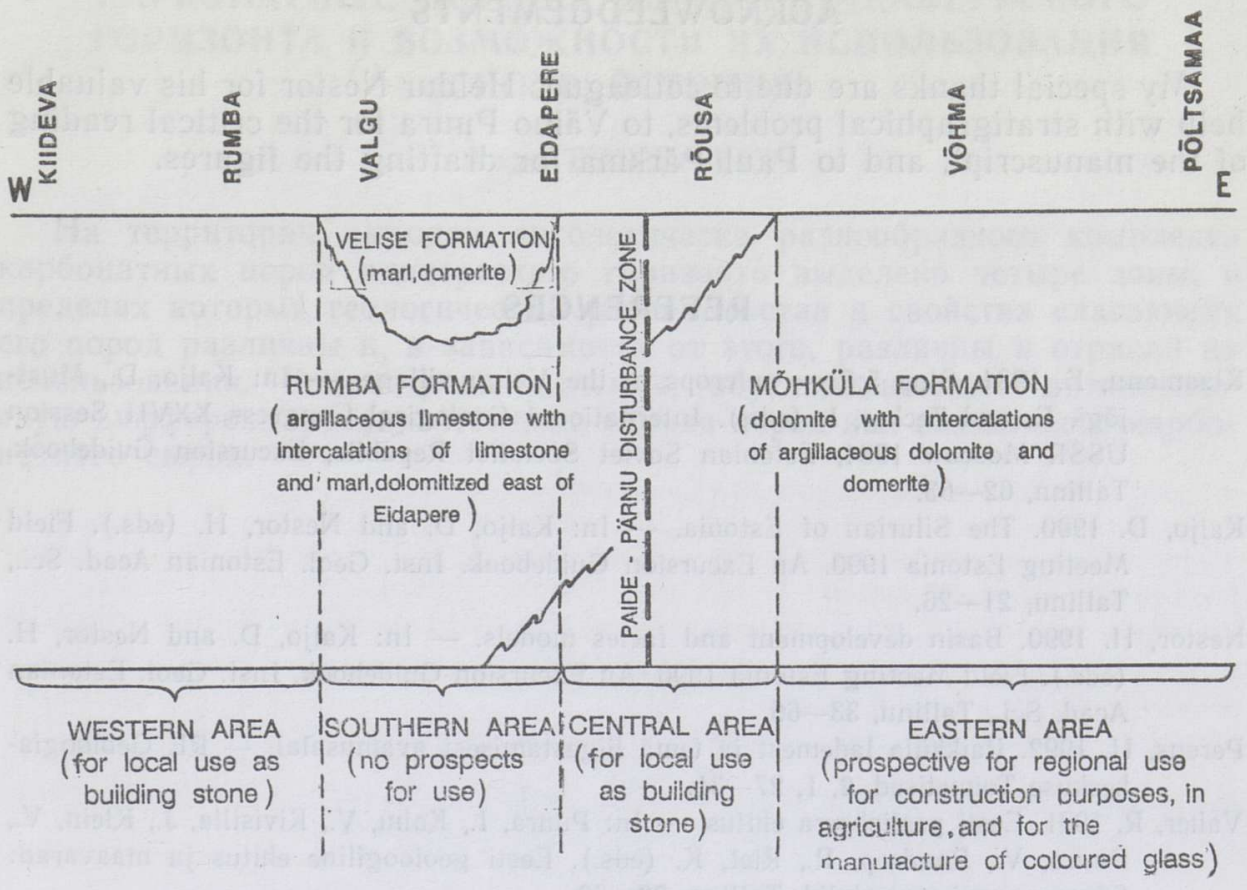

Fig. 3. Schematic lithostratigraphical subdivision and applied zonation of the Adavere Stage in the belt of outcrops.

terrigenous material, have physical-mechanical properties (Table) required for high-quality construction materials and form an important resource on the whole territory through the entire section.

Dolomite used as concrete aggregate must be free from amorphous silica as a subject sensible to an alkaline cement environment. For this reason special tests of concrete have to be made on the sites where the silica nodules are revealed.

The area, constituting the southernmost outcrop of Silurian carbonaceous rocks in southeastern Estonia, has remarkable regional commercial significance. Though the dolomite resources for construction and agricultural purposes are sufficient to meet all foreseeable needs, the increased restrictions to land use may notably reduce, in some cases to a minimum, the quarrying feasibility of known or explored resources. Out of the deposits situated in this area (Fig. 1) only one, Rõstla, is currently quarried. It yields aggregate for different construction purposes, whereas in case of need the washing is applied.

The prospects for the use of dolomites in glass industry are confined to the categories other than colourless glass due to the high content of iron compounds.

\section{CONCLUSIONS}

Based on the regularities of the distribution of rock types in the belt of outcrops of the Adavere Stage, their properties and possible fields of use, there are distinguished four areas with different lithology and correspondingly having different prospects for revealing profitable resources, generalized in Fig. 3. As follows from this figure, the Mõhküla Formation seems to be interpreted not as a coeval unit with the Rumba Formation substituting it laterally, but as a lithostratigraphical unit of earlier age. 


\section{ACKNOWLEDGEMENTS}

My special thanks are due to colleagues Heldur Nestor for his valuable help with stratigraphical problems, to Väino Puura for the critical reading of the manuscript, and to Paul Pärkma for drafting the figures.

\section{REFERENCES}

Klaamann, E. 1984. Stop 5:5 - outcrops in the Valgu village. - In: Kaljo, D., Mustjõgi, E. and Zecker, I. (eds.). International Geological Congress XXVII Session USSR Moscow 1984, Estonian Soviet Socialist Republic, Excursion Guidebook. Tallinn, $62-63$.

Kaljo, D. 1990. The Silurian of Estonia. - In: Kaljo, D. and Nestor, H. (eds.). Field Meeting Estonia 1990. An Excursion Guidebook. Inst. Geol. Estonian Acad. Sci., Tallinn, 21-26.

Nestor, H. 1990. Basin development and facies models. -- In: Kaljo, D. and Nestor, H. (eds.). Field Meeting Estonia 1990. An Excursion Guidebook. Inst. Geol. Estonian Acad. Sci., Tallinn, 33-66.

Perens, H. 1992. Raikküla lademest ja tema liigestamisest avamusalal. - RE Geoloogiakeskuse Toimetised, $2,1,27-31$.

Vaher, R. 1991. Eesti pealiskorra ehitus. - In: Puura, I., Kalrı, V., Kivisilla, J., Klein, V., Puura, V., Raudsep, R., Riet, K. (eds.). Eesti geoloogiline ehitus ja maavarad: Sümpoosiumi materjalid. Tallinn, 30-32.

Қальо Д. 1970. Адавереский горизонт. - In: Кальо Д. (ед.). Силур Эстонии. Валгус, Таллинн, $232-243$.

Қийпли Т. 1984. Перспективы поисков химического карбонатного сырья в Эстонской CСР. - In: Раукас А. (ed.). Хронология и формирование четвертичного покрова Эстонии. Ин-т геол. АН ЭССР, Таллинн, 65-75.

Пальмре Х. 1960. Металлические полезные ископаемые. - In: Орвику К. (ed.). Геология СССР, 28. Эстонская ССР. Госгеолтехиздат, Москва, 400-406.

Решения межведомственного стратиграфического совещания по ордовику и силуру Восточно-Европейской платформы 1984 г. с региональными стратиграфическими схемами. 1987. ВСЕГЕИ и ИГ ЭССР. Ленинград.

Тээдумяэ А. 1986. Промышленные типы карбонатных пород Эстонской ССР. - Изв. АН ЭССР. Геол., 35, 1, 27-34.

Эйнасто Р., Нестор Х., Кала Э., Каяк К. 1972. Сопоставление верхнелландовериїских разрезов в Западной Эстонии. - Изв. АН ЭССР. Хим. Геол., 21, 4, 333-343.

Юргенсон Э. 1964. Снлурийские метабентониты Эстонской ССР. - In: Бауков С. (ed.). Литология палеозойских отложений Эстонии. Ин-т геол. АН ЭССР, Таллинн, $87-101$.

Юргенсон Э. 1966. Литология лландоверийских отложений Эстонин. Ин-т геол. АН ЭССР, Таллинн, $38-46$.

\section{ADAVERE LADEME AVAMUSALA KARBONAATKIVIMID JA NENDE KASUTUSVÕIMALUSED (SILUR, EESTI)}

\section{Aada TEEDUMAE}

Adavere lademe litoloogiliselt mitmekesise karbonaatkivimite kompleksi avamusalal eristub neli piirkonda oma geoloogilise läbilõike, kivimilise ja ainelise koostise ning sellest tulenevate omaduste ning kasutusvõimaluste poolest. Käsitlust on leidnud kivimilise muutlikkuse põhjused ja kasutamisväärse toorme leviku geoloogilised eeldused. 


\section{КАРБОНАТНЫЕ ПОРОДЫ ВЫХОДОВ АДАВЕРЕСКОГО ГОРИЗОНТА И ВОЗМОЖНОСТИ ИХ ИСПОЛЬЗОВАНИЯ (СИлуР, эстония)}

\section{Аада ТЭЭдумЯЭ}

На территории выходов литологически разнообразного комплекса карбонатных пород адавереского горизонта выделено четыре зоны, в пределах которых геологический разрез, состав и свойства слагающих его пород различны и, в зависимости от этого, различны и отрасли их использования. Рассмотрены аспекты, обусловливающие литологическую дифференцированность, дана оценка пород как возможного карбонатного сырья. 